\title{
Oxidative stress biomarkers in Senegal sole, Solea senegalensis, to assess the impact of heavy metal pollution in a Huelva estuary (SW Spain): Seasonal and spatial variation
}

\author{
Milagrosa Oliva ${ }^{\mathrm{a}, *}$, Juan José Vicente ${ }^{\mathrm{b}}$, Carlos Gravato $^{\mathrm{c}}$, Lucia Guilhermino ${ }^{\mathrm{c}}$, \\ María Dolores Galindo-Riaño ${ }^{\mathrm{b}}$ \\ ${ }^{a}$ Biology Department, Marine and Environmental Science Faculty, (University of Cadiz), Avda. República Saharaui S/N, Puerto Real (Cadiz), 11510, Spain \\ ${ }^{\mathrm{b}}$ Analytical Chemistry Department. Sciences Faculty (University of Cadiz), Puerto Real (Cadiz), Spain

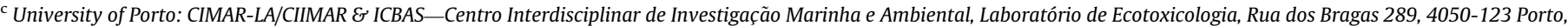 \\ Portugal. ICBAS_Instituto de Ciências Biomédicas de Abel Salazar, Laboratório de Ecotoxicologia, Lg. Prof. Abel Salazar 2, 4099-003 Porto, Portugal
}

\section{A R T I C L E I N F O}

Article history:

Received 19 November 2010

Received in revised form

7 August 2011

Accepted 15 August 2011

Available online 19 September 2011

Keywords:

Oxidative stress

Biomarkers

Heavy metals

Solea senegalensis

\begin{abstract}
A B S T R A C T
The response of wild fish to heavy metals was studied in sole (Solea senegalensis) collected in 2004, 2005 and 2006 at three sampling sites from Huelva estuary (SW Spain), in the vicinity of a petrochemical and mining industry. Heavy metals $\mathrm{As}, \mathrm{Cd}, \mathrm{Cu}, \mathrm{Fe}, \mathrm{Pb}$ and $\mathrm{Zn}$ were analyzed in samples collected from sediment, water and tissue (liver) to examine their bioconcentration and effects in fish such as lipid peroxidation (LPO), catalase (CAT; EC 1.11.1.6), glutathione peroxidase (GPx; EC 1.8.1.7), glutathione S-transferase (GST; EC 2.5.1.18) and glutathione reductase (GR; EC 1.11.1.6) were also analyzed in the fish liver. The results showed different effects in sole from diverse locations with varying degrees of pollution. Significant differences in LPO, CAT and GR activities between control fish and fish from sampling sites were observed as well as seasonal differences for biomarkers. Significant correlations were established between some biomarkers and heavy metals concentrations in liver, sediment and water. This study indicates the usefulness of integrating a set of biomarkers to assess the effects of pollutants in aquatic environments under complex mix of pollutants and chronic pollution situation.
\end{abstract}

(c) 2011 Elsevier Inc. All rights reserved.

\section{Introduction}

Natural and anthropogenic factors produce oxidative stress in the aquatic biota (Winston and Di Giulio, 1991; Kelly et al., 1998). Xenobiotics may stimulate the generation of reactive oxygen species (ROS): $\mathrm{O}_{2}^{-}, \mathrm{H}_{2} \mathrm{O}_{2}, \cdot \mathrm{OH}$, etc. (Halliwell and Gutteridge, 1999) and increased levels of ROS often enhance antioxidant defenses.

Aquatic organisms are exposed to significant amount of heavy metals from industrial, agricultural and anthropogenic activities. Metal accumulation causes an increase in ROS leading to oxidative stress in fish (Roche and Bogé, 1993; Dautremepuits et al., 2002). Heavy metals can promote oxidative damage by directly increasing the cellular concentration of ROS and by reducing the cellular antioxidant capacity (Pinto et al., 2003).

Overproduction of ROS in response to environmental stress can lead to increased lipid peroxidation (LPO) and may affect cell viability by causing membrane damage and enzyme inactivity

\footnotetext{
* Corresponding author. Fax.: + 34956016019

E-mail address: milagrosa.oliva@uca.es (M. Oliva).
}

(Nordberg and Arnér, 2001). Cell senescence, apoptosis and oxidation of nucleic acids and proteins may be accelerated. Antioxidant enzymes such as GST, GPx, GR and CAT usually act in a coordinated manner in order to ensure the optimal protection against oxidative stress (Storey, 1996; Hermes-Lima, 2004).

High heavy metal concentrations have been found in the Ría of Huelva, where Tinto and Odiel rivers flow into Atlantic Ocean together forming a common estuary (Elbaz-Poulichet et al., 1999). Anthropogenic activities can be considered one of the most important sources of the metal pollution: urban sewage inputs, lixiviation of phosphogypsum deposits and finally the industrial activities along the Ría of Huelva (covering fertilizer plants, paper processing and oil refineries). Other pollutants found in Ria de Huelva estuary such as PAHs or PCBs (Jiménez-Tenorio et al., 2007) are also known to influence the biomarkers analyzed in this work. The effects of other compounds as aromatic polycyclic hydrocarbon (PAHs) on these biomarkers in Solea senegalensis from Ria de Huelva estuary have been described by Oliva et al. (2010). Nevertheless, concentrations of compounds such as mentioned above are insignificant compared with heavy metals concentrations in the zone. 
In this work, LPO and antioxidant enzymes represented by enzymes like catalase (CAT) and enzymes related with glutathione: glutathione peroxidase (GPx), glutathione-S-transferase (GST) and glutathione reductase (GR) have been studied. Field experiments are usually performed to determine whether metabolic enzymes can be used as biomarkers of pollution effected months or years following an oil spill event (Gagnon and Holdway, 1999). Thus, antioxidant enzymes play a crucial role in maintaining cell homeostasis. These enzymes have been proposed as biomarkers of contaminant-mediated oxidative stress in a variety of marine organisms, and their induction and/ or inhibition reflects a specific response to pollutants (Jee and Kang, 2005).

Benthic fish, such as sole, into direct contact with sediments, feed on benthic invertebrates that accumulate metals, increasing the toxicity of these compounds through bioaccumulation/biomagnification process. S. senegalensis has been chosen for this study due to its great economic and commercial interest. It is also one of the most abundant and representative species of Atlantic and Mediterranean coasts. S. senegalensis is a well adapted species in warm climates and commonly exploited in extensive aquaculture production in Spain and Portugal (Drake et al., 1984; Dinis, 1992), and have been used in field and laboratory toxicity assays being a sensitive species to heavy metals toxicity (Oliva et al., 2009; Costa et al., 2009). This species is a flat fish with a practically sedentary life and a very territorial biology. This species only realizes one migration per year to the coastal zone in the spawning period (March-June). Larvae, after completing the metamorphosis, are swept to the coast and go into the estuarine zones, being the contact between fish and polluted sediment of the estuary prolonged.
The main of this work is the study of the relationships between heavy metals and oxidative stress enzymes and its utility as metallic pollution biomarkers.

\section{Material and methods}

\subsection{Sampling sites}

Tinto and Odiel River flow together to the Atlantic Ocean forming a common canal known as Canal del Padre Santo belonging to the Ria de Huelva. Three sampling sites were selected in this area of the southwest coastal of Spain (Fig. 1). The first one was located near Odiel River mouth in front of the Atlantic Copper factory $\left(37^{\circ} 13.5^{\prime} \mathrm{N} 6^{\circ} 57.2^{\prime} \mathrm{W}\right)$; the second one was located near Tinto River mouth in front of the dock of La Rábida near phosphogypsum deposits $\left(37^{\circ} 12.5^{\prime} \mathrm{N} 6\right.$ $56^{\prime} \mathrm{W}$ ) and the last one was located at Palos's industrial park in front of the Cepsa oil refinery of the Rábida (Huelva) $\left(37^{\circ} 09.9^{\prime} \mathrm{N} 6^{\circ} 54.8^{\prime} \mathrm{W}\right)$, in the common canal of Odiel and Tinto River, Canal del Padre Santo.

Samples of sediment, water and fish were collected from the three sampling sites in October 2004-May 2006, during autumn (samplings in October 2004 and October 2005) and spring (samplings in April 2005 and May 2006). Physicochemical parameters of sampling sites are included in Table 1.

\subsection{Fish collection}

Specimens of Senegal sole $S$. senegalensis were collected at each sampling site for each sampling period and were transported in aerated tanks to Mazagon's port (Huelva). A total of $97(125.04 \pm 27.12 \mathrm{~g}$ of weight, $23.14 \pm 1.8 \mathrm{~cm}$ of length) fish were dissected and samples of liver of each fish were taken. Fish tissue samples were transported to the laboratory into nitrogen liquid and stored at $-80^{\circ} \mathrm{C}$. Due to all fish collected was juveniles (mainly immature) date of gender and growth of the fish were considered no significant. The specimens captured had a lower size than the reproductive size $(25-30 \mathrm{~cm})$, being probable to live around two-three years in the same zone.

Twelve specimens of $S$. senegalensis $(182.52 \pm 23.89 \mathrm{~g}$ of weight, $25.27 \pm 0.78 \mathrm{~cm}$ of length) used like an unpolluted or control fish, were obtained from the aquaculture facilities of the Faculty of Marine and Environmental

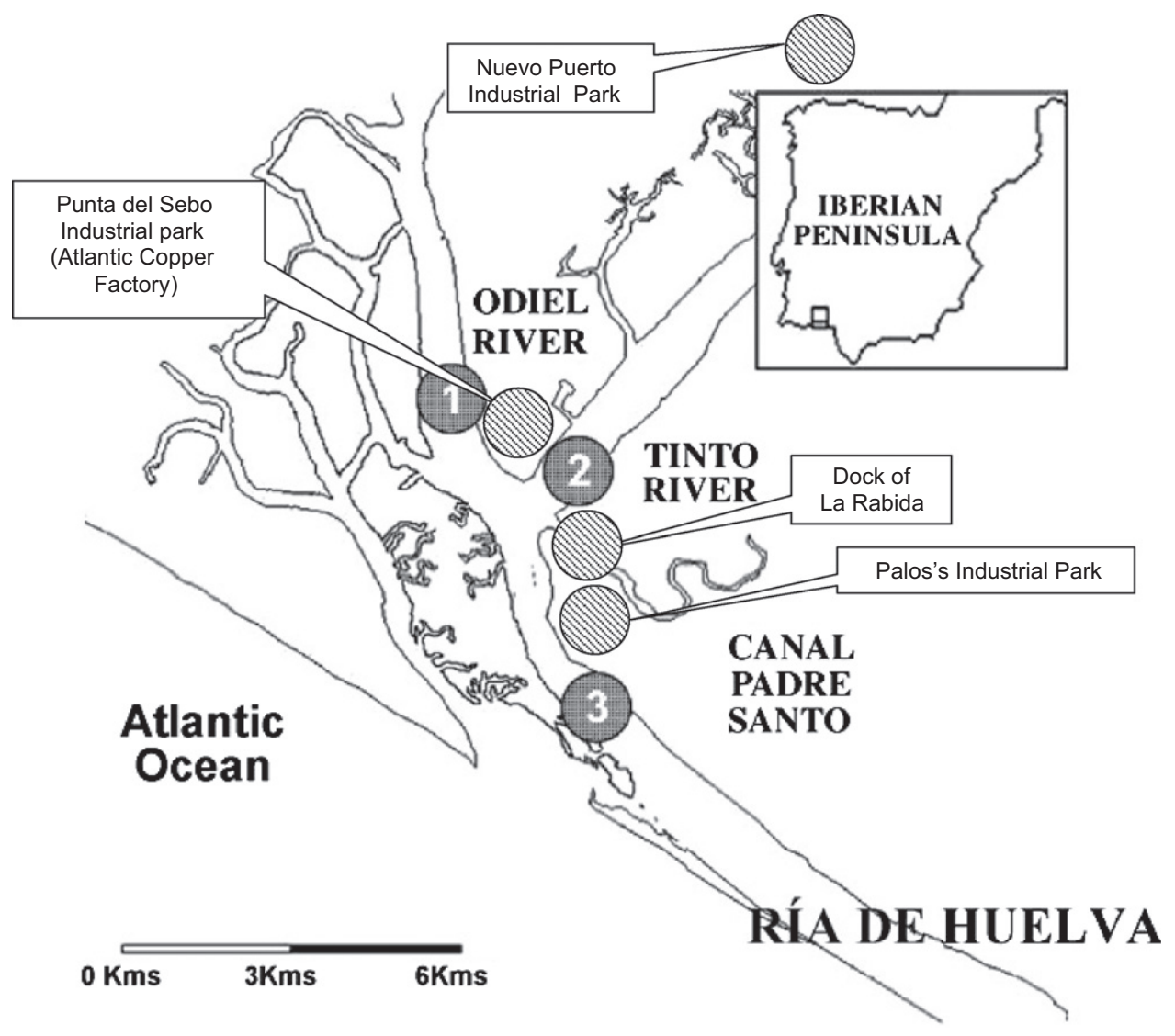

Fig. 1. Location map of sampling sites in Huelva (Spain): 1 (Odiel river); 2 (Tinto river) and 3 (Padre Santo Canal). 
Sciences (University of Cadiz, Spain) in autumn season. It was not possible to get sole juveniles from these aquaculture facilities in spring season. They are only grown in fall using tanks containing seawater but without sediment. For this reason, the significance differences for biomarkers between wild and control fish in the autumn season were only included.

The experiments described comply with the Guidelines of the European Union Council (86/609/EU), the Spanish Government (RD 1201/2005), and the University of Cadiz (Spain) for the use of animals in research.

\subsection{Heavy metals analysis in fish}

Collected fish specimens were dissected and tissue samples from liver were taken. Freeze-dried samples of liver $(0.2 \mathrm{~g})$ were acid digested by microwave

\section{Table 1}

Physico-chemical parameters in water. Sampling sites: (1) Odiel River; (2) Tinto River and (3) Padre Santo Canal.

\begin{tabular}{llllll}
\hline Date & $\begin{array}{l}\text { Sampling } \\
\text { station }\end{array}$ & $\mathrm{pH}$ & $\begin{array}{l}\text { Dissolved } \\
\text { oxygen } \\
\left(\mathrm{mg} \mathrm{L}^{-1}\right)\end{array}$ & $T^{\circ} \mathrm{C}$ & $\begin{array}{l}\text { Salinity } \\
\left(\mathrm{g} \mathrm{L}^{-1}\right)\end{array}$ \\
\hline October 2004 & 1 & 7.85 & 6.30 & 24.0 & 35.8 \\
& 2 & 7.82 & 6.40 & 23.9 & 36.1 \\
& 3 & 8.01 & 6.74 & 23.9 & 35.2 \\
April 2005 & 1 & 8.14 & 11.31 & 18.0 & 32.4 \\
& 2 & 8.21 & 7.45 & 18.7 & 32.4 \\
October 2005 & 1 & 8.37 & 9.25 & 17.3 & 33.9 \\
& 2 & 7.87 & 8.40 & 20.0 & 34.7 \\
& 3 & 7.86 & 7.45 & 20.8 & 34.6 \\
May 2006 & 1 & 8.15 & 13.60 & 21.1 & 35.2 \\
& 2 & 7.74 & 13.32 & 22.1 & 30.2 \\
October 2007 & Control & 8.02 & 6.7 & 21.7 & 29.5 \\
\hline
\end{tabular}

heating using $4 \mathrm{ml}$ of $65 \% \mathrm{HNO}_{3}$ (Suprapur) and $2 \mathrm{~mL}$ of $30 \% \mathrm{H}_{2} \mathrm{O}_{2}$ (Suprapur); after digestion, samples were diluted up to $25 \mathrm{~mL}$ with Milli-Q deionised water. Metal concentrations of digested tissue samples were analyzed by ICP-MS and ICP-AES, using two replicates for each sample with an error of $<10 \%$. Blanks were also carried out and measured for all metals following the same procedure. The detection limits of metal measurement were performed and the accuracy of methodology applied was satisfactorily evaluated using DOLT-3 (dogfish liver) certified reference material (see Table 2). Data of liver metal concentrations from Tinto River and Padre Santo Canal for October 2004 could not obtain due to handling pollution during acid digestion.

\subsection{Heavy metals analysis in sediments}

Surface sediment samples were collected using a dredge at each point during the four samplings to depth ranging from $2-20 \mathrm{~cm}$ following the EPA recommendation, because most benthic organisms are found in this horizon (EPA, 2003). They were stored in polyethylene bags at $-4{ }^{\circ} \mathrm{C}$ until analysis. Fine particle-size fractions were obtained from the dried grinded and sieved sediments. The BCR sequential extraction (exchangeable, reducible, oxidizable and residue fraction) procedure was applied (Davidson et al., 1999) and speciation and total concentrations of metal were evaluated by ICP-AES or AAS, using two replicates for each sample with an error of $<10 \%$. Blanks were also carried out and measured for all metals following the same procedure. The detection limits of metal measurement were performed and NIST 1646a certified reference estuarine sediment was used for analysis validation (see Table 2).

\subsection{Heavy metals analysis in water}

Samples collection was carried out at each point during the four samplings using a peristaltic bomb and no filtered and filtered samples were obtained in situ by using $0.45 \mu \mathrm{m}$ Calyx Capsule MSI filter connected on line when required. Total metal, particulate metal fraction and dissolved metal fractions (labile organic, labile inorganic, moderately labile inorganic, moderately labile organic and no labile dissolved metal) were analyzed by stripping voltammetry (DPASV) after acid digestion. Dissolved metal speciation was carried out by metal fractionation to different $\mathrm{pH}$ distinguished among labile inorganic and organic metal, moderately labile inorganic and organic metal and inert fraction. In addition, particulate

Table 2

Analytical quality control data for metal analysis in sediment, water and liver.

(a) Metal analysis in sediment ${ }^{\mathrm{a}}$

\begin{tabular}{|c|c|c|c|c|}
\hline \multirow[t]{2}{*}{ Metal } & \multicolumn{2}{|c|}{ Estuarine sediment NIST SRM ${ }^{\mathbb{R}} 1646 a$} & \multicolumn{2}{|c|}{ Analytical parameters of the method } \\
\hline & Certified $\left(\mathrm{mg} \mathrm{Kg}^{-1}\right)$ & Found $\left(\mathrm{mg} \mathrm{Kg}^{-1}\right)$ & Blank $\left(\mu \mathrm{g} \mathrm{L}^{-1}\right)$ & Detection limit ${ }^{\mathrm{b}}\left(\mu \mathrm{g} \mathrm{L}^{-1}\right)$ \\
\hline $\mathrm{Zn}$ & $48.9 \pm 1.6$ & $46.8 \pm 1.8$ & $0.144 \pm 0.094$ & 0.043 \\
\hline $\mathrm{Cd}$ & $0.148 \pm 0.007$ & $0.15 \pm 0.11$ & n.d. ${ }^{c}$ & 0.001 \\
\hline $\mathrm{Pb}$ & $11.7 \pm 1.2$ & $10.8 \pm 0.5$ & $0.202 \pm 0.026$ & 0.098 \\
\hline $\mathrm{Cu}$ & $10.01 \pm 0.34$ & $9.8 \pm 0.5$ & n.d. ${ }^{\mathrm{c}}$ & 0.120 \\
\hline As & $6.23 \pm 0.21$ & $5.93 \pm 0.76$ & n.d. ${ }^{c}$ & 0.156 \\
\hline \multicolumn{5}{|c|}{ (b) Metal analysis in water ${ }^{\mathrm{a}}$} \\
\hline \multirow[t]{2}{*}{ Metal } & \multicolumn{2}{|c|}{ Estuarine water BCR CRM ${ }^{(\mathrm{B})} 505$} & \multicolumn{2}{|c|}{ Analytical parameters of the method } \\
\hline & Certified $\left(\mu \mathrm{g} \mathrm{L}^{-1}\right)$ & Found $\left(\mu \mathrm{g} \mathrm{L}^{-1}\right)$ & Blank $\left(\mu \mathrm{g} \mathrm{L}^{-1}\right)$ & Detection limit ${ }^{\mathrm{b}}\left(\mu \mathrm{g} \mathrm{L}^{-1}\right)$ \\
\hline $\mathrm{Zn}$ & $11.24 \pm 0.719$ & $9.29 \pm 1.55$ & $1.11 \pm 0.08$ & 0.66 \\
\hline $\mathrm{Cd}$ & $0.09 \pm 0.005$ & $0.08 \pm 0.01$ & n.d. ${ }^{c}$ & 0.013 \\
\hline $\mathrm{Pb}$ & $0.05 \pm 0.03$ & $0.09 \pm 0.01$ & $0.166 \pm 0.017$ & 0.042 \\
\hline $\mathrm{Cu}$ & $1.87 \pm 0.095$ & $2.00 \pm 0.13$ & $0.237 \pm 0.014$ & 0.247 \\
\hline As & n.c. ${ }^{d-\infty}$ & - & n.d. ${ }^{c}$ & 0.098 \\
\hline \multicolumn{5}{|c|}{ (c) Metal analysis in liver ${ }^{\mathrm{a}}$} \\
\hline \multirow[t]{2}{*}{ Metal } & \multicolumn{2}{|c|}{ Dogfish liver NRC CRM ${ }^{\mathbb{R}}$ DOLT-3 } & \multicolumn{2}{|c|}{ Analytical parameters of the method } \\
\hline & Certified ( $\mathrm{mg} \mathrm{Kg}^{-1}$ ) & Found $\left(\mathrm{mg} \mathrm{Kg}^{-1}\right)$ & $\operatorname{Blank}\left(\mu \mathrm{g} \mathrm{L}^{-1}\right)$ & Detection limit ${ }^{\mathrm{b}}\left(\mu \mathrm{g} \mathrm{L}^{-1}\right)$ \\
\hline $\mathrm{Zn}$ & $86.6 \pm 2.4$ & $80.28 \pm 6.26$ & $0.64 \pm 0.73$ & 3.71 \\
\hline $\mathrm{Cd}$ & $19.4 \pm 0.6$ & $18.66 \pm 1.04$ & n.d. ${ }^{c}$ & 0.009 \\
\hline $\mathrm{Pb}$ & $0.319 \pm 0.05$ & $0.30 \pm 0.03$ & $0.02 \pm 0.04$ & 0.014 \\
\hline $\mathrm{Cu}$ & $31.2 \pm 1.00$ & $24.18 \pm 3.79$ & $0.49 \pm 0.32$ & 5.21 \\
\hline As & $10.2 \pm 0.5$ & $9.79 \pm 0.57$ & $0.05 \pm 0.03$ & 0.265 \\
\hline
\end{tabular}

${ }^{a}$ Sediment analysis by ICP-AES; Water analysis by DPASV, except As by GHAAS (flame); Liver analysis by ICP-AES for Zn and Cu and ICP-MS for Cd, Pb and As.

${ }^{\mathrm{b}}$ It is calculated as three times standard deviation of blank $(n=8)$ divided by the slope of calibration curve.

c No detected concentration.

${ }^{\mathrm{d}}$ No certified value. 
and organic and inorganic dissolved arsenic species were evaluated by using hydride generation and AAS, with an operational discrimination among fractions. Analytical methods were checked by using CRM 505 certified reference estuarine water. Four replicates for each sample were performed with an error of $<10 \%$. Blanks were measured for all metals following the same procedure and the detection limits of metal measurement were also performed (see Table 2).

\subsection{Instruments and reagents in heavy metals analysis}

Differential pulse anodic stripping voltammetric measurements were obtained by Metrohm 757 VA Computrace Stand with automated hanging mercury drop electrode as working electrode, controlled by PC software VA Computrace 2.0, installed in a personal computer using a 5326 VA Computrace Interface (Metrohm, Switzerland). Atomic spectroscopy measurements were achieved by an inductively coupled plasma emission Iris Intrepid spectrometer (ICP-AES) and X7 Series plasma scan sequential inductively coupled mass spectrometer (ICP-MS) (Thermo Elemental, UK). Hydride generated coupled atomic absorption measurements were carried out by a Solaar $\mathrm{M}$ Series spectrometer (AAS) coupled an HG accessory Unicam VP90 (Thermo Elemental, UK). Organic matter was removed for real water samples by UV irradiation with a Metrohm model 705 UV Digester (Metrohm, Switzerland) in quartz tubes. Microwave assisted digestions were made by an Ethos 1600 microwave heating (Milestone, Italy).

Because of high sensitivity required for trace metal analysis, a strict protocol was followed to avoid contamination of solutions and samples. Low-density polyethylene bottles (LDPE, Nalgene) and polystyrene flasks were acid cleaned and used to store samples and reagent solutions. Sample handling and preparation of solutions were performed using polyethylene gloves under a class 100 laminar flow hood cabinet Crusair model 9005-FL (Cruma, Spain). All the clean material was kept in plastic bags to avoid lab air pollution. Water was purified by reverse osmosis with an Elix 3 (Milli-RO) system followed by ion exchange with an $18 \mathrm{M} \Omega \mathrm{cm}^{-1}$ deionised Milli-Q50 System (Millipore, USA). All reagents for treatment of samples during trace analysis were Suprapur or Ultrapure grade, supplied by Merck (Darmstadt, Germany) or SigmaAldrich (Steinhein, Germany). All solutions were prepared using Milli-Q deionised water. High purity gases were used during analysis purchased by Air Liquid (Spain).

\subsection{Analysis of biomarkers}

Liver was rapidly isolated, frozen and maintained at $-80^{\circ} \mathrm{C}$ until further analysis. Each liver was homogenized (1:10) in $0.1 \mathrm{M} \mathrm{K}$-phosphate buffer ( $\mathrm{pH}$ 7.4). Part of this liver homogenate was used to determine the extent of endogenous LPO by measuring the thiobarbituric acid reactive substances (TBARS), according to Ohkawa et al. (1979) and Bird and Draper (1984), with the adaptations of Filho et al. (2001) and Torres et al. (2002). The remaining liver homogenate was centrifuged for $20 \mathrm{~min}$ at $10,000 \mathrm{~g}$ $\left(4{ }^{\circ} \mathrm{C}\right)$ to obtain the post-mitochondrial supernatant (PMS). GST activity was determined following the conjugation of GSH with 1-chloro-2,4-dinitrobenzene (CDNB) at $340 \mathrm{~nm}$ (Habig et al. 1974). CAT activity was determined in PMS which represents the $\mathrm{H}_{2} \mathrm{O}_{2}$ consumption obtained at $240 \mathrm{~nm}$ in the presence of $\mathrm{H}_{2} \mathrm{O}_{2}$ (Clairbone, 1985). GPx activity was determined in PMS by measuring the decrease in NADPH at $340 \mathrm{~nm}$ and using $\mathrm{H}_{2} \mathrm{O}_{2}$ as a substrate (Mohandas et al., 1984). GR activity was assayed in PMS according to Cribb et al. (1989). The protein concentration of liver PMS was determined according to Bradford (1976).

\subsection{Data set composition and statistical analysis}

A total of 97 samples of fish were included in the analyses; 43 samples representing Odiel River (24 and 19 samples for autumn and spring seasons, respectively), 34 samples representing Tinto River (16 and 18 samples for autumn and spring seasons, respectively) and 20 samples representing Canal del Padre Santo for autumn season.

Statistical analyses were performed using the statistical software package STATISTICA (data analysis software system) version 7 (2004, Statsoft, Inc. USA).

For each data set, the assumptions of analysis of variance (ANOVA), normality and equal variance, were checked using Shapiro-Wilks and Levene tests, respectively. If data set met assumptions, one-way ANOVA was conducted and where significant, a post-hoc mean comparison test (Tukey's test) was realized. If data set not met assumptions, the Kruskal-Wallis and Mann-Whitney (one-tail) tests to find the significant differences were conducted. To analyze the correlation between biomarkers and heavy metals, Pearson and Spearman correlations test was employed by applying the results of 12 samples of sediment and water corresponding to each sampling. All statistical analyses were conducted at an alpha level of 0.05 .

\section{Results}

\subsection{Heavy metals concentrations in fish, water and sediment}

Average concentrations of heavy metals in liver of S. Senegalensis, sediment and water in the different sampling sites and years are shown in Figs. 2-4. Dissolved and particulate metal distribution in water and the speciation of metals in sediment data have been previously published by Vicente Martorel et al. (2009).

Metal contents in liver were ranging over following intervals: Cu: $0.34-1147.8 \mathrm{mg} \mathrm{kg}^{-1}$ dry weight; $\mathrm{Zn}: 0.24-143.06 \mathrm{mg} \mathrm{kg}^{-1}$ dry weight; Fe: $12.90-1135.43 \mathrm{mg} \mathrm{kg}^{-1}$ dry weight; As: $0.0-$ $507.9 \mathrm{mg} \mathrm{kg}^{-1}$ dry weight; $\mathrm{Cd}$ : $0.00-6.6 \mathrm{mg} \mathrm{kg}^{-1}$ dry weight and $\mathrm{Pb}$ : $0.18-6.24 \mathrm{mg} \mathrm{kg}^{-1}$ dry weight. Therefore, the following accumulation ranking could be established: $\mathrm{Cu}>\mathrm{Fe}>\mathrm{Zn}>$ As $>\mathrm{Cd}>\mathrm{Pb}$. Significant differences among sampling sites were not found. On the other hand, seasonal influence was only found for arsenic, with higher values in spring.

High levels of heavy metals were found in sediment ranging over following intervals: Fe: 44689.4-61426.7 $\mathrm{mg} \mathrm{kg}^{-1}$; $\mathrm{Cu}$ : 1115.7-3333.6 mg kg-1; Zn: 602.94-1736.9 mg kg-1; Pb: $136.8-$ $1166.7 \mathrm{mg} \mathrm{kg}^{-1}$; As: $85.1-615.4 \mathrm{mg} \mathrm{kg}^{-1}$ and $\mathrm{Cd}: 1.5-33.2$ $\mathrm{mg} \mathrm{kg}^{-1}$, allowing to arrange the metals from higher to lower mean content in this estuary as: $\mathrm{Fe}>\mathrm{Cu}>\mathrm{Zn}>\mathrm{Pb}>\mathrm{As}>\mathrm{Cd}$. Special attention should be care on $\mathrm{Fe}$ and $\mathrm{Cu}$ concentration because they were very high. It is noteworthy that higher mean values were found in the last point (site 3 ) where estuarine metal deposition process usually happens. Only $\mathrm{Cd}$ mean concentration was higher values in Odiel site. However, significant differences were not found among sites or seasons.

Total metals in water were ranging over following intervals: $\mathrm{Zn}$ : 49.8- 381.6 $\mu \mathrm{g} \mathrm{L}^{-1}$; Cu: 20.9-72.4 $\mu \mathrm{g} \mathrm{L}^{-1}$; Pb: 2.6-17.8 $\mu \mathrm{g} \mathrm{L}^{-1}$; As: 2.6-9.3 $\mu \mathrm{g} \mathrm{L}^{-1}$ and $\mathrm{Cd}: 0.7-8.9 \mu \mathrm{g} \mathrm{L}^{-1}$. The metal concentrations can be arranged as follows (higher to lesser contents): $\mathrm{Zn}>\mathrm{Cu}>\mathrm{P}$ $\mathrm{b} \approx \mathrm{As}>\mathrm{Cd}$. Generally, content of metal in Tinto and Odiel sites were higher than content of metal in the Canal del Padre Santo site, where metal precipitation diminished the contents in water. Otherwise, slight higher mean values were found for $\mathrm{Zn}$ and $\mathrm{Cu}$ in Tinto samples comparing Odiel ones. Conversely, higher mean values were found for $\mathrm{Pb}$ in Odiel water. Nevertheless, spatial variability was not found. The other metals showed similar values in both sites. Significant seasonal variability for $\mathrm{Cu}$ and $\mathrm{Zn}$ in water was found, being their concentrations higher during spring. Similar results were found for $\mathrm{Zn}, \mathrm{Cd}$ and $\mathrm{Pb}$ dissolved levels.

Based on the speciation analysis, $\mathrm{Cu}, \mathrm{Zn}$ and $\mathrm{Cd}$ were the most available metal in both water and sediment. This chemical result was in agreement with the significant correlation $(r=0.732$, $p=0.039$ ) found between $\mathrm{Cu}$ concentration in liver and $\mathrm{Cu}$ concentration in sediment, probably due to the benthic behavior of sole fish. Thus, the metal accumulation was more influenced by the sediment pollution.

\subsection{Biomarkers and heavy metals concentrations}

Only LPO and GR showed spatial and temporal significant differences $(p \leq 0.05)$. In relation to spatial differences, LPO showed significant differences between all three sampling sites in autumn 2005. GR showed significant differences between Odiel and Tinto River in spring 2006. In all cases it was observed that higher values of biomarkers in Tinto River (Fig. 5) as $\mathrm{Cu}$ and $\mathrm{Zn}$ pollution in water.

With regard to temporal differences $(p \leq 0.05)$, LPO showed significant differences in Odiel and Tinto River between: autumn 2004 and autumn 2005; spring 2005 and autumn 2005 and autumn 2005 and spring 2006. GR showed a significant difference in Odiel River between autumn 2005 and spring 2006. LPO and GR values were higher in autumn season (Fig. 5).

Significant differences $(p \leq 0.05)$ between LPO and CAT responses in control fish and fish from sampling sites in autumn season were observed in Odiel and Tinto River (Fig. 5). Due to absence of control fish in spring season, significant differences observed between biomarkers analyzed in wild fish captured in 

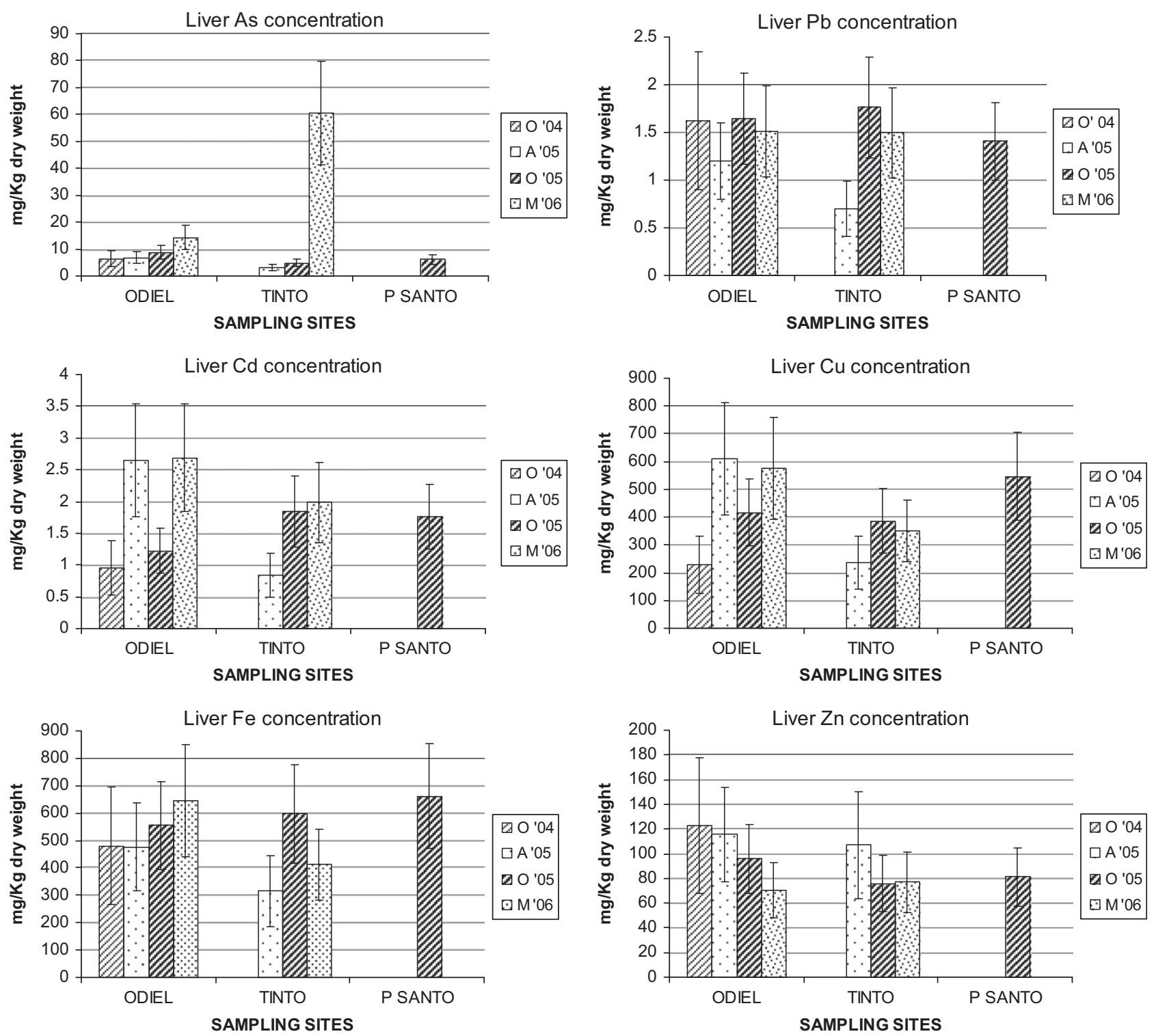

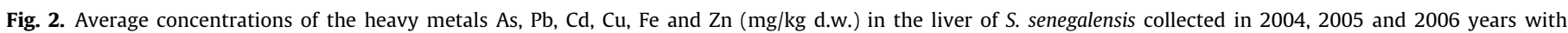
corresponding ES bars. (O: October, A: April and M: May).

spring season and control fish used in this work (captured in autumn season) are not included.

Significant correlations (Spearman and Pearson Correlation Coefficients, $p \leq 0.05$ ) were analyzed between biomarkers (LPO, CAT, GPx, GR and GST) and heavy metals concentrations (As, Pb, $\mathrm{Cd}, \mathrm{Cu}, \mathrm{Fe}$ and $\mathrm{Zn}$ ) in liver, sediment and water. On the one hand, the concentrations of different metals in liver were correlated with biomarker activities found in fish tissues. On the other hand, the average of each biomarker activity was used to study the correlation among different metals fraction in water and sediment with the biomarkers in fish from each sampling and sampling site.

Liver enzyme activities such as CAT and GR were correlated with the hepatic concentrations of $\mathrm{Zn}(r=-0.365, p=0.005), \mathrm{Pb}$ $(r=-0.291, p=0.031)$ and $\mathrm{Cd}(r=0,315, p=0.020)$ in liver, respectively.

Correlationships between several enzymatic activities in liver and heavy metal concentrations in sediment were also established: LPO-As oxidizable $(r=0.143, p=0.010)$, LPO-Cd total $(r=0.700, p=0.036)$, LPO-Cd oxidizable $(r=0.733, p=0.025)$,
LPO-Fe reducible $(p=0.013, r=0.745)$ and $\mathrm{GPX}-\mathrm{Cu}$ reducible $(r=-0.663, p=0.037)$.

Correlationships between several enzymes and heavy metals concentrations in water were also observed: LPO-As inorganic $(r=0.6718, p=0.033)$, LPO-Cd moderately labile inorganic dissolved $(r=-0.713, p=0.021)$, LPO-Zn labile organic dissolved $(r=0.632$, $p=0.05)$, LPO-Zn moderately labile inorganic $(r=-0.681, p=0.030)$, CAT-Cd no labile $(r=-0.688, p=0.028)$, GST-Zn moderately labile inorganic dissolved $(r=-0.681, p=0.030)$, GST-Zn total $(r=-0.661$, $p=0.038)$ and GST-Cu particulate $(r=-0.685, p=0.029)$.

\section{Discussion}

\subsection{Heavy metals concentrations in sediments, water and fish.}

Estuaries are zones of complex interaction between fluvial and marine processes that act as geochemical trap for heavy metals. Due to processes of co-precipitation that happen when metal-rich waters of the rivers mix with seawater and increase of $\mathrm{pH}$, the 

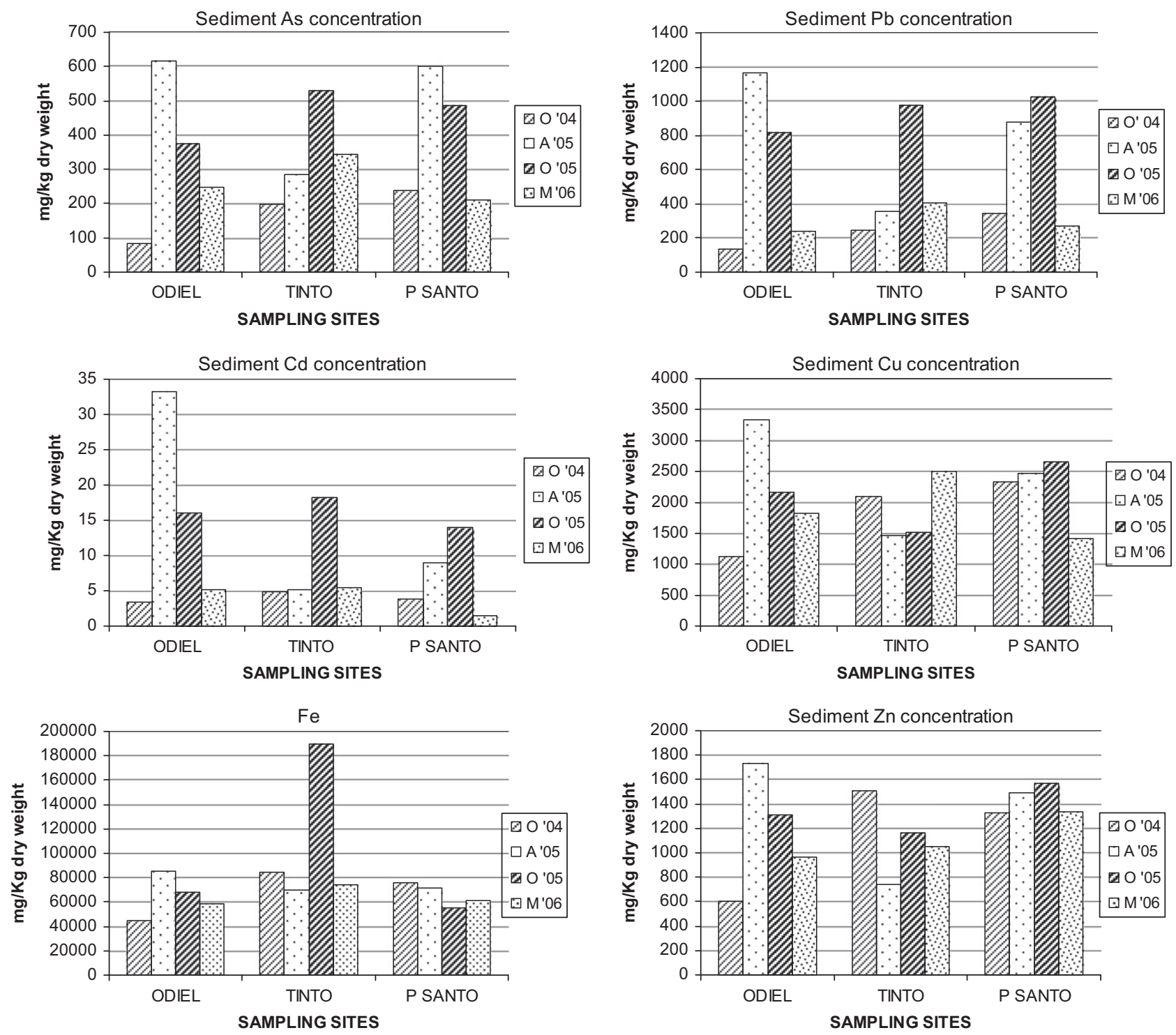

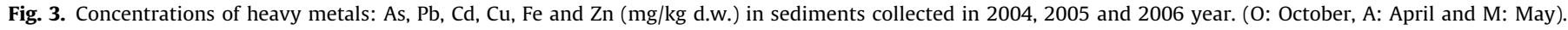

content of metal in sediment of estuary (Canal del Padre Santo) were higher than the content in the rivers (Odiel and Tinto River).

Concentrations of heavy metals in sediments were compared with Canadian sediment quality guidelines (ISQG, interim marine sediment quality guidelines and PEL, probable effects levels) and NOAA guidelines for the protection of aquatic life (ERL, level of effects range low and ERM, level of effects range medium). All metals studies showed higher concentrations than quality criteria, outstanding $\mathrm{Cu}$ with very high values. $\mathrm{Pb}$ which some lower values than ERM guideline on 2004 autumn was an exception; in addition, Cd exceeded ERL and ISQG criteria for all samples and PEL criterion during autumn 2005. The increase of heavy metals in autumn 2005 could be due to a long period of low rainfalls. $\mathrm{Cu}$ concentration were very high.

In order to assess the potential hazardous impacts, the heavy metal levels in water were also compared with quality guidelines for protection of aquatic life proposed by several organizations guidelines (USEPA, 2002) and imperative values of regional government (BOJA, 1997). However, concentration values of As, $\mathrm{Cd}$ and $\mathrm{Pb}$ were lower than those proposed by EPA criteria of maximum concentration (CMC) and continuous concentration
(CCC), both established to prevent from acute and chronic toxicity to aquatic organisms, respectively.

Quality guidelines for Fe in fish liver, water and sediment were not found, probably due to its low toxicity even at high concentrations.

High $\mathrm{Cu}$ and $\mathrm{Zn}$ levels were observed in liver tissue in accordance with higher total content and more available metals in both water and sediment. Generally, the levels of metal in liver samples were higher than FAO/WHO limits values, but these ones are usually referred to muscle and fish pool not being comparables.

\subsection{Biomarkers: seasonal and spatial variation.}

Significant differences $(p<0.05)$ in the response of LPO and GR between autumn and spring seasons were found for Odiel and Tinto Rivers being the response in AUTUMN > SPRING. In the sampling zone, the autumn season showed higher temperature than spring season.

Consideration of seasonal variations is essential during biomonitoring programs when sampling is done at different periods of the year. Seasonal variations in physico-chemical parameters and heavy metals concentrations in sediments, water and liver of 

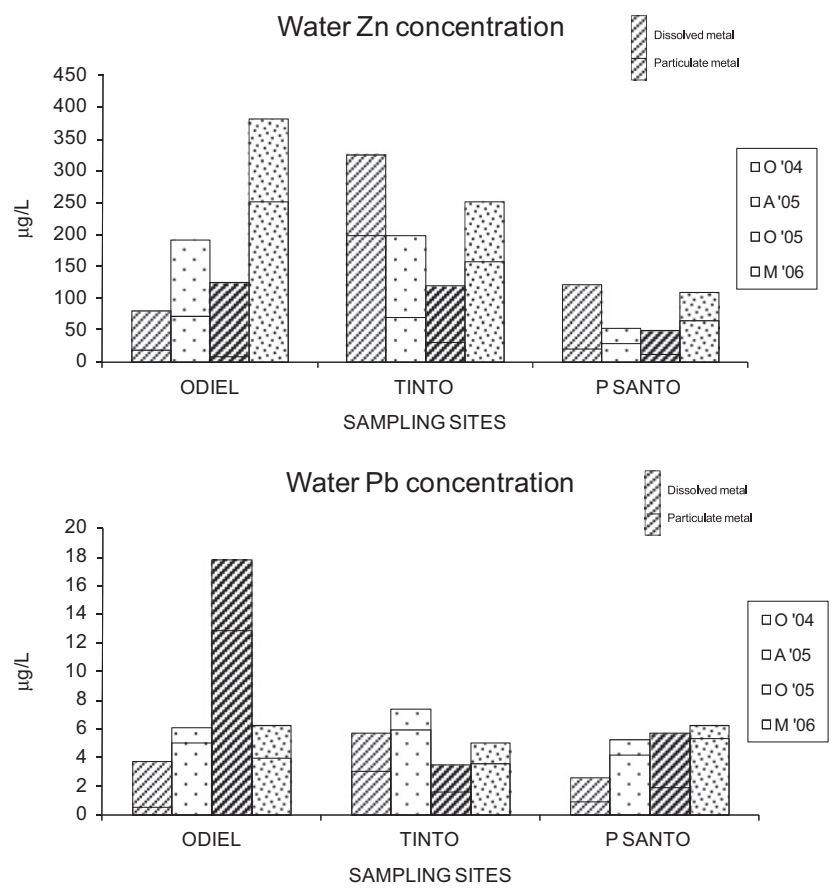
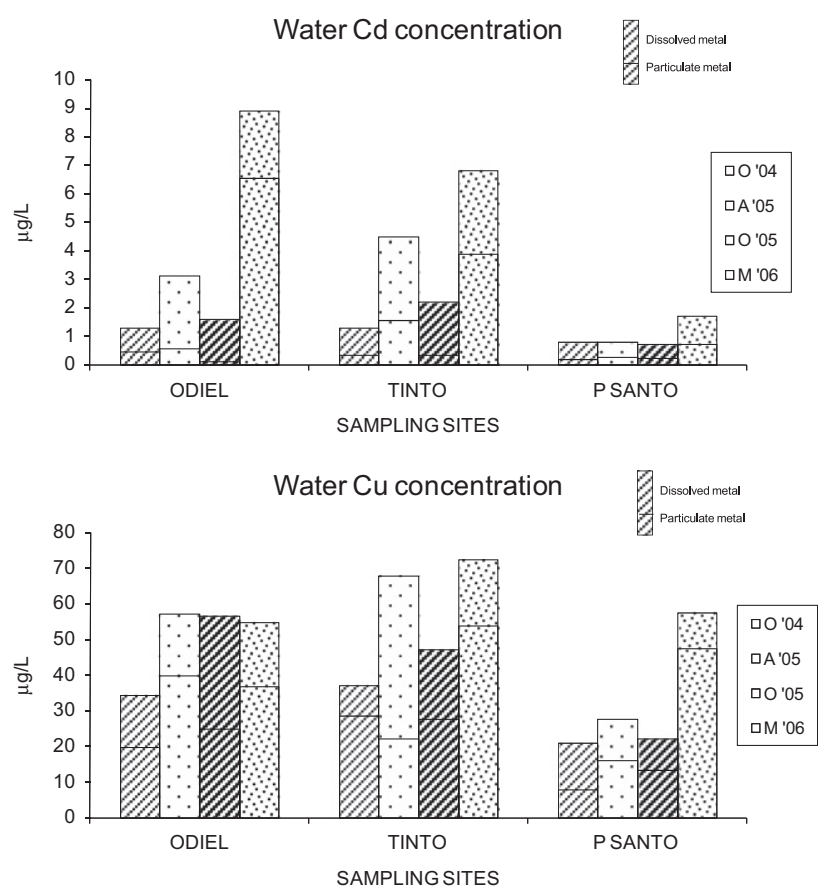

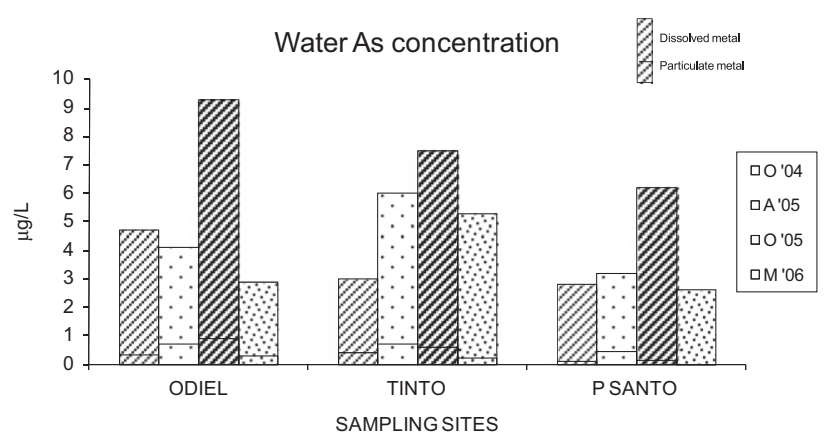

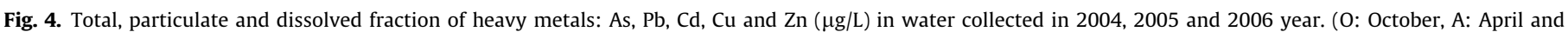
M: May).

S. Senegalensis in Huelva estuary have been reported by Vicente Martorel et al. (2009).

Amado et al. (2006) observed significant differences in LPO (contaminated and no contaminated sites) values between summer and winter seasons in Micropogonias furnieri. Values were higher in the warmer season. Padmini et al. (2008), Padmini and Vijaya Geetha (2009) also observed in Mugil cephalus an oxidative stress (LPO) was more severe during summer than the monsoon (cold season) in polluted estuary fish, but no significant difference in the results was observed between the seasons in unpolluted estuary fish. Same response in LPO was observed by Aras et al. (2009) in three species of Salmo trutta where values of LPO were higher in autumn than spring.

Regard to GR activity, Aras et al. (2009) also observed a higher GR activity in liver of two different species of $S$. trutta during spring season, with water in spring season showing higher temperature than autumn season.

A possible explanation to the increase of LPO and GR activity with the temperature is the increased polyunsaturation of mitochondrial membranes in fish than raise rates of mitochondrial respiration, which would in turn enhance the formation of ROS, increase proton leak and favor peroxidation of these membranes. Higher levels of organic hidroperoxides are formed by enhanced lipid mobilization, which leads to induction of higher GPx activity. This induces enhanced utilization of GSH, forming their oxidized form (GSSG) and influences elevated activity of GR in order to maintain sufficient amount of reduced equivalents in the cells and thus normal redox homeostasis. Theoretically, temperature and food availability induce oxygen consumption and cellular oxyradical generation, which are compensated by increasing antioxidant defense (Manduzio et al., 2004).

Control fish used in this study were analyzed to stress oxidative biomarkers in autumn season, but no control animal was analyzed in spring season. Therefore, both pollutant concentrations on the environment and natural variations could have affected to stress oxidative biomarkers in S. senegalensis. Many other factors, however, could also influence metabolism and enzymatic activities, e.g. mode of life and feeding habits (Ronisz et al., 1999) that were not assessed in the present study.

\subsection{Correlationship between heavy metals and biomarkers}

As above mentioned significant differences $(p<0.05)$ between LPO and CAT responses in control fish and fish from sampling sites in autumn season were observed in Odiel and Tinto River. The marker levels indicated the lipid peroxidation and damage caused by increased oxidative stress. In the literature, studies focused on the use of biomarker to assess the toxicity of heavy metals have been carried out using total metal concentration in water and/or sediment; however, speciation of metals has been scarcely used. In this paper, this novelty statement is accomplished. 

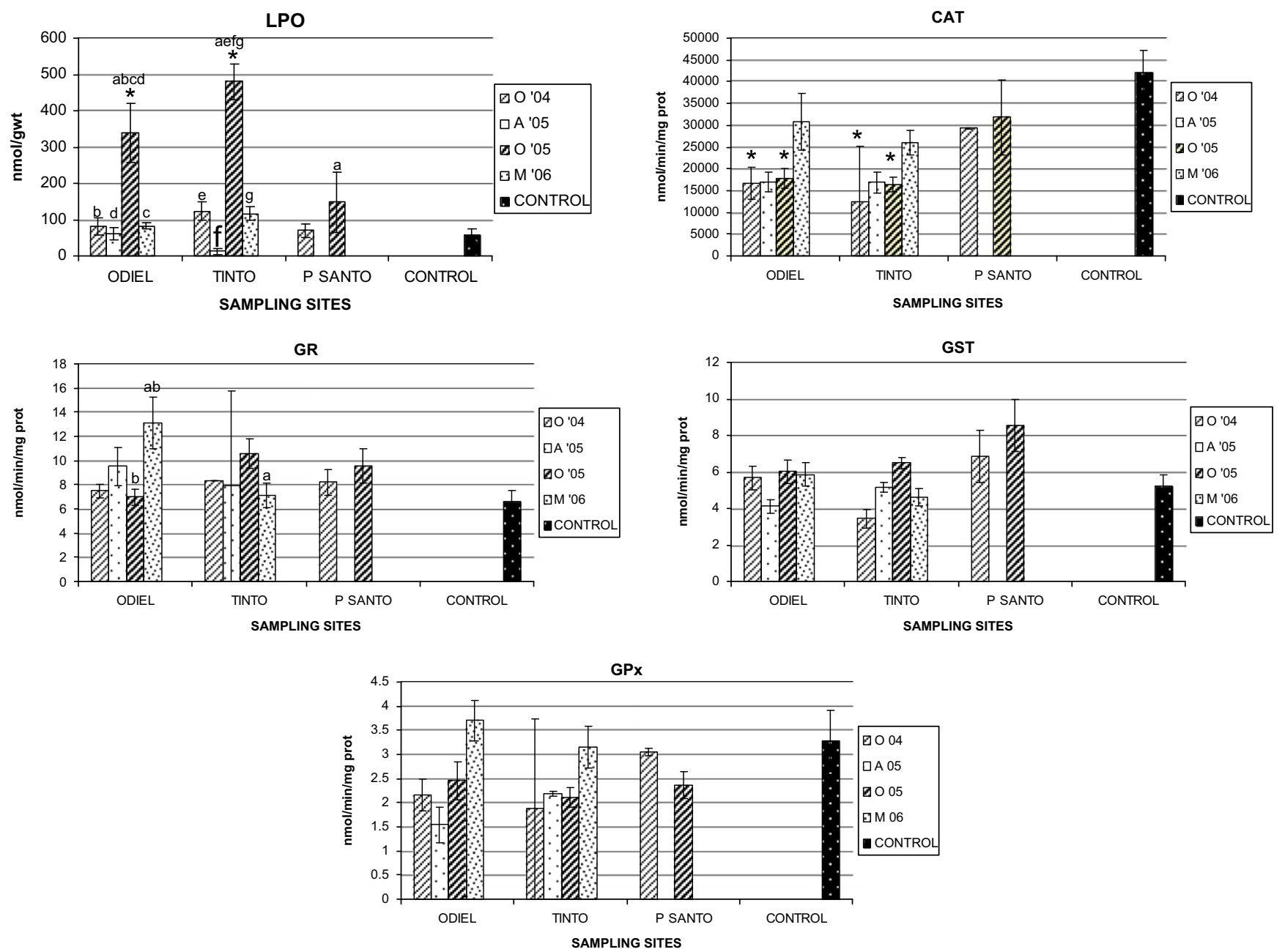

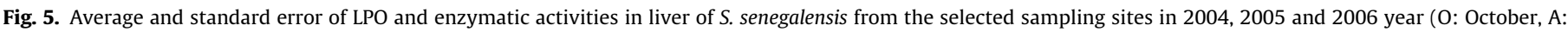

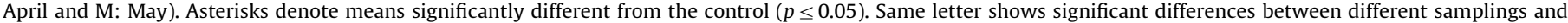
sampling sites $(p \leq 0.05)$.

The majority of positive correlations between metals concentrations in water and enzymatic activities in liver were observed with the labile dissolved fraction of metals. In the same sense, positive correlations were observed with the oxidizable fraction of metals in sediment. Regard to negative correlations observed between metals and enzymatic activity, no labile or particulate fraction of metals in water and metal reducible fraction in sediment correlated with ones. It should be mentioned that correlation coefficients were higher than 0.5 among enzymatic activities and metal concentrations in water and lower than 0.5 when metal levels in sediment were studied.

$\mathrm{Cd}$ and $\mathrm{Zn}$ led a major number of correlations with biomarkers analyzed.

In the study, cadmium concentration correlated positively with LPO, GR and CAT biomarkers. Thus, LPO activity presented a negative correlation with the moderately labile inorganic cadmium fraction (labile fraction are the most available) in water and a positive correlation with the oxidizable and total concentration of cadmium in sediment.

It is known that $\mathrm{Cd}$ produces toxic effects in fish, including hepatotoxicity and cancerogenicity. The tissue damaging effects of this heavy metal are widely believed to be associated with its ability to generate free radicals, which cause peroxidation of cell membrane lipids (Asagba et al., 2004). Lipid peroxidation is the oxidation of polyunsaturated lipid consequence of oxidative stress. The process of LPO proceeds by a chain reaction (a single radical species propagate a number of deleterious biochemical reactions).

Nawaz et al., 2005 observed in hepatocytes of Cyprinus carpio exposed to $1 \mu \mathrm{M}$ Cd significant elevation of TBARS after $6 \mathrm{~h}$ of exposure to $\mathrm{Cd}$. The lack of enhanced ROS production with $\mathrm{Cd}$ despite elevated lipid peroxidation is in agreement with earlier findings (Watjen and Beyersmann, 2004). This corroborates the notion that $\mathrm{Cd}$ is not directly involved in redox cycling, but rather exerts its toxic action via interference with membrane stability and cellular antioxidative protection mechanisms (Stohs et al., 2001). Nevertheless, Asagba et al. (2008) not observed significant change in the level of LPO in Clarias gariepinus exposed to $0.1,0.2$ and $0.4 \mathrm{ppm}$ of $\mathrm{Cd}$ and it may be attributed to the nondetectable level of cadmium in liver for a short period of exposure. Asagba also observed an increase activity of superoxide dismutase enzyme (SOD) and the corresponding decrease in LPO in the liver of C. gariepinus exposed to cadmium for 21 days like an indication of a delayed and/or adaptive response to mobilization of $\mathrm{Cd}$ into this organ. The tendency of the liver to tolerate Cd-induced oxidative stress is believed be due to the ability of this organ to synthesize metallothioneines (MT) rapidly and efficiently (WHO, 1992).

On the other hand, GR activity correlated positively with the total concentration of $\mathrm{Cd}$ in liver of $\mathrm{S}$. senegalensis. No similar response to data was found in the revised literature; however, a similar behavior was observed in mammals. Sheweita (1998) observed an increase of GSH-R activity in the liver of the rats 
exposed to $2 \mathrm{mg} / \mathrm{kg}$ of $\mathrm{Cd}$ that could be an adaptive response of the animals in order to compensate for the depleted GSH level. The total GSH level seems to depend not only on the reduction of GSSG but also on other sources of GSH synthesis, since the heavy metals which depleted GSH level also increased the activity of GSH-R.

Other biomarker related to cadmium concentration was catalase activity. CAT activity presented a negative correlation with the no labile fraction of cadmium in water. CATs are hematin-containing enzymes that facilitate the removal of hydrogen peroxide $\left(\mathrm{H}_{2} \mathrm{O}_{2}\right)$, which is metabolized to molecular oxygen $\left(\mathrm{O}_{2}\right)$ and water. Since CATs are localized in the peroxisomes of most cells and are involved in fatty acid metabolism, changes in activities may often be difficult to interpret (Stegeman et al., 1992).

Vaglio and Landriscina (1999) observed in Sparus aurata exposed to $2.5 \mathrm{mg} / \mathrm{kg}$ body weight of $\mathrm{CdCl}_{2}$ during 3 and 6 days a decreasing in the liver CAT activity and Elia et al. (2007) also observed a time-dependent negative correlation between $\mathrm{Cd}$ concentration and CAT activity in Ameiurus melas exposed to different concentrations of $\mathrm{Cd}$. Other authors such as Pruell and Engelhardt (1980) observed a liver CAT activity inhibited following both in vivo and in vitro exposure to dissolved $\mathrm{Cd}^{2+}$ at a concentration higher than $1 \mathrm{mg} / \mathrm{L}$ in the killfish (Fundulus heteroclitus) and the authors suggested a direct effect of $\mathrm{Cd}^{2+}$ on high molecular weight compounds like catalase.

Zinc is other metal more correlated with biomarkers activity in this work. $\mathrm{Zn}$ is essential as a cofactor for many enzymes (e.g. $\mathrm{Cu}$ / $\mathrm{Zn}$-SOD) and also shows an important function in transcription of many genes involved in cellular protection against ROS. At high levels, $\mathrm{Zn}$ can also cause osmoregulatory disturbances in aquatic organisms and may also cause cytotoxic effects in the presence of hydrogen peroxide $\left(\mathrm{H}_{2} \mathrm{O}_{2}\right)$ (Chung et al., 2005).

Biomarkers such as CAT, GST or LPO correlated with $\mathrm{Zn}$ in this work. CAT presented a negative correlation with total concentration of $\mathrm{Zn}$ in liver. $\mathrm{H}_{2} \mathrm{O}_{2}$ is the main cellular precursor of the hydroxyl radical, which is a highly reactive and toxic form of ROS. Thus, $\mathrm{H}_{2} \mathrm{O}_{2}$ removal by CAT is an important strategy of marine organisms against oxidative stress (Regoli et al., 2002). In addition, ROS overproduction such as superoxide anion (Ahmad et al., 2000), may also lead to CAT activity decrease. Therefore, ROS-induced toxicity maybe considered as the probable cause for liver CAT activity decrease (inhibition) (Maria et al., 2009). The data point out CAT inhibition as an alternative signal of environmental degradation, which is in agreement with Regoli and Principato (1995), who suggested this effect as a transitory response to acute pollution.

GST showed a negative correlation with moderately labile inorganic fraction and total concentration of $\mathrm{Zn}$ in water. A similar response was observed by Lopes et al. (2001) in Leuciscus alburnoides from $\mathrm{Zn}$ polluted river and Franco et al. (2008) observed in Cyprinus carpio exposed to $10-100 \mu \mathrm{M} Z \mathrm{Zn}$ a slight reduction in GST activity representing an impaired capacity to detoxify toxic compounds.

Regard to LPO, a positive correlation with the labile organic fraction of $\mathrm{Zn}$ and a negative correlation with moderately labile inorganic fraction in water were found.

Gioda et al. (2007) observed in Leporinus obtusidens exposed to 2.3 and $4.6 \mathrm{mg} / \mathrm{L}$ for a small but significant increase in liver TBARS contents dependent on the concentration and time of exposure; the increase in TBARS levels were observed only at the highest concentration studied $(4.6 \mathrm{mg} / \mathrm{L})$. These results clearly indicate that prolonged exposure to sublethal concentrations of zinc is associated with oxidative stress.

Other metals such us arsenic, lead and/or copper also presented correlations with biomarkers activities.

Cellular toxicity of arsenic is mediated through the binding of sulfhydryl groups of critical proteins, but may also be caused by oxidative stress resulting from intracellular oxidation-reduction reactions of the various forms of arsenic. Arsenite is significantly more toxic than arsenate, which has been shown to be reduced to arsenite by cellular sulphydryls such as glutathione. Although methylation has been shown to reduce the toxicity of inorganic arsenic and enhance elimination, methylated arsenical species have been shown to elicit oxidative damage in mice (Schlenk et al., 1997).

In the present study, LPO showed a positive correlation with the dissolved inorganic arsenic in water: more toxic fraction of the dissolved arsenic.

Allen et al. (2004) also observed in Channa punctatus a significant increase of LPO alter $7 \mathrm{~d}$ of exposure to $1 \mathrm{mg} / \mathrm{L}$ of arsenic. Bhattacharya and Bhattacharya (2007) observed Clarias Batrachus exposed to 8.4 and $4.2 \mathrm{mg} / \mathrm{L}$ arsenic and observed this sequence for LPO, which increased in the initial days of exposure, it showed a first peak on day 2, and after that it gradually decreased to the basal level, presenting a second peak on day 7 and subsided on day 10 .

Finally, the toxicity of arsenic in animals depends on the species, sex, age, dose and duration of exposure. Arsenic toxicity studies in fish mostly dealt with chronic exposure to low-dose arsenic and indicated that may or may not induce LPO, depending on the species involved.

Regard to lead; the presence of $\mathrm{Pb}$ in marine water is due to a variety of anthropogenic activities related to the increasing mining operations and industrial use (Ruvio, 1972). In aquatic biota, $\mathrm{Pb}$ concentrations are usually highest in benthic organisms, and lowest in upper trophic level predators. GR presented a negative correlation with the total concentration of lead in liver of $S$. senegalensis.

The responses of fish GR to pollutants have apparently received little attention and a lack of information about toxicity of $\mathrm{Pb}$ and GR activity in fish liver have been observed after consulting related bibliography.

GR merits attention because of its importance in maintaining GSH/GSSG homeostasis under oxidative stress conditions (Winston and Di Giulio, 1991). GR has a disulfide bond in its active site, but lead interferes with the disulfide bond and inhibits the enzyme. This inhibition prevents the reduction of GSSG, making cells more susceptible to oxidative damage.

In general works about glutathione enzymes such us Thomas and Juedes one (1992) showed that chronic exposure to lead caused increase in hepatic glutathione concentrations. It was observed a relationship between metal accumulation and glutathione increase after lead exposure. They showed that for lead, at least, the increase in glutathione is due to a stimulation of syntheses, rather than a decrease in utilization of the tripeptide. Normally, glutathione acts in a negative feedback manner on its own synthesis, so the elevations in rate of synthesis caused by xenobiotics may reflect a change in set point.

The elevation in glutathione may help protect the cell from lipid peroxidation and aid in maintenance of mitochondrial calcium content.

Other metal related to biomarkers activity was copper, being one of the most accumulated heavy metals in the samples. Copper concentration presented several correlations with GST and GPx biomarkers.

Copper catalyzes the hydroxyl radical production and lipid peroxidation in biological systems. Copper is an essential trace metal abundantly present in aquatic environment and it tends to accumulate in the liver of fish. In small amounts, copper is needed for hemoglobin synthesis and is a major component of a number of enzymes but when copper concentration exceeds the metabolic requirement, it becomes toxic to fish. Copper is reported to have a functional role in iron absorption and the mobilization of stored 
iron in mammals. Copper- and iron-containing metalloenzymes, such as the superoxide dismutases, peroxidases and catalase, have a common and integrated role in the destruction of ROS.

GST presented a negative significant correlation with the particulate copper in water. The conjugation of electrophilic compounds with GSH is catalyzed by the glutathione S-transferases (GSTs). Besides their essential functions in intracellular transport and the biosynthesis of leukotrienes and prostaglandins, a critical role for GSTs is the defense against oxidative damage and peroxidative products of DNA and lipids. Martinez-Lara et al. (1996) found a decrease in GST activity in gilthead seabream (Sparus aurata) exposed to pollutants and suggested that these results could be due to inactivation by ROS generated by pollutants. Amado et al. (2006) observed in M. furnieri from a Cu polluted site a decreasing of GST activity in the two different seasons (winter and summer). Gravato et al. (2006) observed the same effect in Anguilla anguilla exposed to $2.5 \mu \mathrm{M} \mathrm{Cu}$ and preexposure to $\beta$-naphthoflavone; in this case, this enzymatic inhibition may also be due to the role of GST in cell protection against the effects of genotoxic compounds (Hayes and Pulford, 1995.

Another biomarker related to copper concentration was GPx, presenting a positive significant correlation with the reducible fraction of copper in the sediment. GPx catalyzes the metabolism of $\mathrm{H}_{2} \mathrm{O}_{2}$ to water, involving the oxidation of reduced oxidized $\mathrm{GSH}$ form (GSSG). GPX is considered to play an important role in protecting membranes from damage due to LPO. This observation led to the view that the major detoxification function of GPx is the termination of radical chain propagation by quick reduction to yield further radicals (Van der Oost et al., 2003). Possible mechanisms to explain this fact may include direct metal-mediated structural alteration of the enzymes producing a depression of CAT and GPx synthesis (Winston and Di Giulio, 1991).

Finally, iron is a necessary element for life because it is an essential component of enzymes such as catalase and various types of cytochromes. However, in a free form, iron can react with oxygen species or with molecular oxygen to yield additional oxygen radicals (including lipid peroxides) via Fenton-type chemistry or reactive iron-oxygen complexes. The addition of iron to unsaturated fatty acids, liver microsomes or liposomes initiates lipid peroxidation. Iron ions can take part in electron-transfer reactions with molecular oxygen-producing superoxide anion. Superoxide in the presence of iron and superoxide dismutase can dismutate to form hydrogen peroxide and a hydroxyl radical via the Fenton reaction (Matta et al., 1999).

LPO presented a positive significant correlation with the reducible fraction of iron in sediment. Bagnyukova et al. (2006) observed in Carassius auratus exposed to 20 or $500 \mu \mathrm{M}$ of iron sulphate an increase of LPO in 1.4-2.5 fold, with respect to control fish and a significant increase of lipid peroxidation was observed by Hamoutene et al. (2000) in S. trutta when phospholipids (liposomes, lipids from microsomes and salmon liver microsomes) were incubated with 2\% iron. Quian and Buettner (1998) hypothesized that the Fenton reaction with pre-existing $\mathrm{H}_{2} \mathrm{O}_{2}$ is only a minor initiator of free-radical oxidations, and the major initiators of biological freeradical oxidations are the oxidizing species formed by the reaction of $\mathrm{Fe}^{2+}$ with dioxygen. When $\left[\mathrm{O}_{2}\right] /\left[\mathrm{H}_{2} \mathrm{O}_{2}\right] \geq 100, \mathrm{Fe}^{2+}+\mathrm{O}_{2}$ chemistry is presumably of major importance in the initiation of detrimental biological free-radical oxidation.

Sheehan and Power (1999) concluded that the use of biomarkers, such us enzyme activities in biomonitoring studies is often complicated, because levels of chemical pollutants in the environment often display wide seasonal variations in response to climate and other factors. A part of variation recorded for oxidative stress biomarkers cannot be explained by season and could be linked to species, modification of food availability, spawning period, kind of pollution or other environmental factors. The interpretation of the responses of theses biomarkers in a biomonitoring context appear difficult and require and accurate well characterization of sampling site. Nevertheless, multi-biomarker approach provided improved understanding of the diverse responses and effects of exposure to contaminants, and the effective risk it poses for different fish species (Fonseca et al., 2011).

\section{Conclusions}

The pollution of Huelva estuary has been taken account by Spanish administration and the waste management policy changed in 1997. Several restorations have been proposed but the problem of presence of the high concentration of metals in this ecosystem keeps on affecting to the aquatic life.

The increase of heavy metals concentrations in autumn 2005 coincides with the increase of the LPO values and the decrease of the CAT values for the same season.

Biomarkers response was in general higher in warmer season (autumn) but more multi-annual experiments are needed to characterise accurately the natural variability of biomarkers in S. Senegalensis in wild fish from non-polluted or control zone.

Few studies have been realized about the relation between stress oxidative biomarkers responses and the speciation or fraction of heavy metals. The chemical speciation is necessary in toxicological studies to understand the effect of the complex mixes of pollutants in the environment. It has been observed that correlations between biomarkers and different fractions of the metals studied; analyzing only the total concentrations of metals had not been able to explain. It is necessary to realize a multivariate analysis including all the variables studied in this work to study deeply the synergist and antagonist effects between the different metallic fractions and biomarkers as well as between the biomarkers.

\section{Acknowledgments}

This work has been supported by the Project SEAPAT: "Biomarkers and histopathology in gilthead seabream, Sparus aurata and Senegal sole, Solea senegalensis" (CICYT, REN 2003-09361CO3-03) and by the Project SEAMET: "Bioavailability of heavy metals in aquatic ecosystems affected by diffuse pollution" (CICYT, REN 2003-09361-CO3-02, Spain Government).

\section{References}

Ahmad, I., Hamid, T., Fatima, M., Chand, H.S., Jain, S.K., Athar, M., Raisuddin, S. 2000. Induction of hepatic antioxidants in freshwater fish (Channa punctatus B.) is a biomarker of paper mill effluent exposure. Biochim. Biophys. Acta 1523, 37-48.

Allen, T., Singhal, R., Rana, S.V., 2004. Resistance to oxidative stress in a freshwater fish Channa punctatus after exposure to inorganic arsenic. Biol. Trace Elem. Res. 98 (1), 63-72.

Amado, L.L., Da Rosa, C.E., Leite, A.M., Moraes, L., Pires, W.V., Pinho, G.L., Martins C.M., Robaldo, R.B., Nery, L.E., Monserrat, J.M., Bianchini, A., Martinez, P.E., Geracitano, L.A., 2006. Biomarkers in croakers Micropogonias furnieri (Teleostei: Sciaenidae) from polluted and non-polluted areas from the Patos Lagoon estuary (Southern Brazil): evidences of genotoxic and immunological effects. Mar. Pollut. Bull. 52 (2), 199-206.

Aras, N.M., Bayir, A., Sirkecioglu, A.N., Bayir, M., Aksakal, E., Haliloglu, H.I., 2009 Seasonal changes in antioxidant defense system of liver and gills of Salmo trutta caspius, Salmo trutta labrax and Salmo trutta macrostigma. J. Fish Biol. 74 (4), 842-856

Asagba, S.O., Eriyamremu, G.E., Adaikpoh, M.A., Ezeoma, A., 2004. Levels of lipid peroxidation, superoxide dismutase and $\mathrm{Na}+/ \mathrm{K}+-$ ATPasa in some tissues of rats exposed to a Nigerian-like diet and cadmium. Biol. Trace Elem. Res. 100 (1), 143-154. 
Asagba, S.O., Eriyamremu, G.E., Igberaese, M.E., 2008. Bioaccumulation of cadmium and its biochemical effect on selected tissues of the catfish (Clarias gariepinus). Fish Physiol. Biochem. 34 (1), 61-69 2008.

Bagnyukova, T.V., Chahrak, O.I., Lushchak, V.I., 2006. Coordinated response of goldfish antioxidant defenses to environmental stress. Aquat. Toxicol. 78 (4), 325-331.

Bhattacharya, A., Bhattacharya, S., 2007. Induction of oxidative stress by arsenic in Clarias batrachus: involvement of peroxisomes. Ecotoxicol. Environ. Saf. 66 (2), 178-187.

Bird, R.P., Draper, A.H., 1984. Comparative studies on different methods of malondyhaldehyde determination. Methods. Enzymol. 90, 105-110.

BOJA num. 27 de 4/3/1997, pp. 2591-2598, 1997. Orden de 14 de febrero de 1997 por la que se clasifican las aguas afectadas directamente por vertidos, en desarrollo del Decreto 14/1996, de 16 de enero, por el que se aprueba el Reglamento de calidad de aguas litorales.

Bradford, M.M., 1976. A rapid and sensitive method for quantification of microgram quantities of protein utilizing the principle of protein-dye-binding. Anal. Biochem. 72, 248-254.

Chung, M.J., Walker, P.A., Brown, R.W., Hogstrand, C., 2005. Zinc-mediated gene expression offers protection against $\mathrm{H}_{2} \mathrm{O}_{2}$-induced cytotoxicity. Toxicol. Appl. Pharmacol. 205, 225-236.

Clairbone, A., 1985. Catalase activity. In: Greenwald, R.A. (Ed.), CRC Handbook of Methods in Oxygen Radical ResearchCRC Press, Boca Raton, Fl, pp. 283-284.

Costa, P.M., Diniz, M.S., Caeiro, S., Lobo, J., Martins, M., Ferreira, A.M., Caetano, M., Vale, C., Del Valls, T.A., Costa, M.H., 2009. Histological biomarkers in liver and gills of juvenile Solea senegalensis exposed to contaminated estuarine sediments: A weighted indices approach. Aquat. Toxicol. 92 (3), 202-212.

Cribb, A.E., Leeder, J.S., Spielberg, S.P., 1989. Use of a microplate reader in assay of glutathione reductase using 5.5'-dithiobis(2-nitrobenzoic acid). Anal. Biochem. 183, 195-196.

Dautremepuits, C., Betoulle, S., Vernet, G., 2002. Antioxidant response modulated by copper in healthy or parasitized carp (Cyprinus carpio L.) by Ptychobothrium sp. (Cestoda). BBA-Gen. Subjects 1573, 4-8.

Davidson, M.C., Lorna, E.W., Ure, A.M., 1999. Effect of sample preparation on the operational speciation of cadmium and lead in freshwater sediment. Fresenius J. Anal. Chem. 363, 134-136.

Dinis, M.T., 1992. Aspects of the potential of Solea senegalensis Kaup for aquaculture: Larval rearing and weaning to an artificial diet. Aquacult. Fish. Manag. 23, 179-183.

Drake, P.A. Arias, M., Rodríguez, A., 1984. Cultivo extensivo de peces marinos en los esteros de las salinas de San Fernando (Cádiz): II. Características de la producción de peces. Fisheries Res. Institute (Spain) (Technical Report) 116, 1-23.

EPA (Environmental Protection Agency), 2003. Literature Review and Report Surface-Sediment Sampling Technologies. Project no. G1058.3.1.03.104.02.

Elbaz-Poulichet, F., Morley, N.H., Cruzado, A., Velásquez, Z., Achterberg, E.P. Braungardt, C.B., 1999. Trace metal and nutrient distribution in an extremely lox pH (2.5) river-estuarine system, the Ria of Huelva (South-west Spain). Sci. Total Environ. 227, 73-83.

Elia, A.C., Dörr, A.J., Galarini, R., 2007. Comparison of organochlorine pesticides, PCBs, and heavy metal contamination and of detoxifying response in tissues of Ameiurus melas from Corbara, Alviano, and Trasimeno Lakes, Italy. B. Environ. Contam. Toxicol. 78 (6), 463-468.

Filho, D.W., Tribess, T., Gáspari, C., Cláudio, F.D., Torres, M.A., Magalhaes, A.R.M., 2001. Seasonal changes antioxidant defenses of the digestive gland of the brown mussel (Perna perna). Aquaculture 203, 149-158.

Fonseca, V.F., França, S., Serafim, A., Company, R., Lopes, B., Bebianno, M.J., Cabral, H.N., 2011. Multi-biomarker responses to estuarine habitat contamination in three fish species: Dicentrarchus labrax, Solea senegalensis and Pomatoschistus microps. Aquat. Toxicol. 102 (3-4), 216-227.

Franco, J.L., Posser, T., Mattos, J.J., Sánchez-Chardi, A., Trevisan, R., Oliveira, C.S., Carvalho, P.S., Leal, R.B., Marques, M.R., Bainy, A.C., Dafre, A.L., 2008. Biochemical alterations in juvenile carp (Cyprinus carpio) exposed to zinc: Glutathione reductase as a target. Mar. Environ. Res. 66 (1), 88-89.

Gagnon, M.M., Holdway, D.A., 1999. Metabolic enzyme activities in fish gills as biomarkers of exposure to petroleum hydrocarbons. Ecotoxicol. Environ. Saf. $44,92-99$.

Gioda, C.R., Lissner, L.A., Pretto, A., Da Rocha, J.B.T., Schetinger, M.R.C., Neto, J.R. Morsch, V.M., Loro, V.L., 2007. Exposure to sublethal concentrations of $\mathrm{Zn}$ (II) and $\mathrm{Cu}(\mathrm{II})$ changes biochemical parameters in Leporinus obtusidens. Chemosphere 69, 170-175.

Gravato, C., Teles, M., Oliveria, M.A., Santos, M.A., 2006. Oxidative stress, live biotransformation and genotoxic effects induced by copper in Anguilla anguilla L. - the influence of pre-exposure to $\beta$-naphthoflavone. Chemosphere 65 , 1821-1830.

Habig, W.H., Pabst, M.J., Jakoby, W.B., 1974. Glutathione-S-transferases, the first enzymatic step in mercapturic acid formation. J. Biol. Chem. 249, 7130-7139.

Halliwell, B., Gutteridge, J.M.C., 1999. Free Radicals in Biology and Medicine. Oxford University Press, Oxford.

Hamoutene, D., Rahimtula, A., Payne, J., 2000. Iron ore mines leachate potential for oxyradical production. Ecotox. Environ. Saf.. 46, 218-224.

Hayes, J.D., Pulford, D.J., 1995. The glutathione S-transferase supergene family: Regulation of GST and the contribution of the isoenzymes to cancer chemoprotection and drug resistance. Crit. Rev. Biochem. Mol. Biol 30, 445-600.

Hermes-Lima, M., 2004. Oxygen in biology and biochemistry: role of free radicals. In: Storey, K.B. (Ed.), Functional Metabolism: Regulation and AdaptationWileyLiss, Hoboken, pp. 319-368.
Jee, J.H., Kang, J.C., 2005. Biochemical changes of enzymatic defence system after phenanthrene exposure in olive flounder, Paralichthys olivaceus. Physiol. Res. 54, 585-591.

Jiménez-Tenorio, N., Morales-Caselles, C., Kalman, J., Salamanca, M.J., De Canales, M.L., Sarasquete, C., Del Valls, T.A., 2007. Determining sediment quality for regulatory proposes using fish chronic bioassays. Environ. Int. 33 (4), 474-480.

Kelly, K.A., Havrilla, C.M., Brady, T.C., Abramo, K.H., Levin, E.D., 1998. Oxidative stress in toxicology: Established mammalian and emerging piscine model systems. Environ. Health Perspect. 106 (7), 375-384.

Lopes, P.A., Pinheiro, T., Santos, M.C., Mathias, M.L., Collares-Pereira, M.J., ViegasCrespo, A.M., 2001. Response of antioxidant enzymes in freshwater fish populations (Leucistus alburnoides complex) to inorganic pollutants exposure. Sci. Total Environ. 280, 153-163.

Manduzio, H., Monsinjon, T., Galap, C., Leboulenger, F., Rocher, B., 2004. Seasonal variations in antioxidant defence in blue mussels Mytilus edulis collected from a polluted area: Major contributions in gills of an inducible isoform of $\mathrm{Cu} / \mathrm{Zn}$ superoxide dismutase and of glutathione-S-transferase. Aquat. Toxicol. 70, 83-93.

Maria, V.L., Ahmad, I., Oliveira, M., Serafim, A., Bebianno, M.J., Pacheco, M., Santos, M.A., 2009. Wild juvenile Dicentrarchus labrax L. liver antioxidant and damage responses at Aveiro Lagoon. Portugal. Ecotoxicol. Environ. Saf. 72 (7), 1861-1870.

Martinez-Lara, E., Toribio, F., López-Barea, J., Bárcena, J.A., 1996. Glutathione-Stransferase isoenzyme patterns in the gilthead seabream (Sparus aurata) exposed to environmental contaminants. Comp. Biochem. Physiol. 113, 215-220.

Matta, J., Milad, M., Manger, R., Tosteson, T., 1999. Heavy metals, lipid peroxidation, and ciguatera toxicity in the liver of the Caribbean barracuda (Sphyraena barracuda). Biol. Trace Elem. Res. 70 (1), 69-79.

Mohandas, J., Marshall, J.J., Duggins, G.G., Horvath, J.S., Tiller, D., 1984. Differential distribution of glutathione and glutathione related enzymes in rabbit kidney. Possible implications in analgesic neuropathy. Cancer Res. 44, 5086-5091.

Nawaz, M., Manzl, C., Krumschnabel, G., 2005. In vitro toxicity of copper, cadmium and chromium to isolated hepatocytes from carp, Cyprinus carpio L. B. Environ. Contam. Toxicol. 75, 652-661.

Nordberg, J., Arnér, E.S.J., 2001. Reactive oxygen species, antioxidants, and the mammalian thioredoxin system. Free Radic. Biol. Med. 31, 1287-1312.

Ohkawa, H., Ohisi, N., Yagi, K., 1979. Assay for lipid peroxides in animal tissues by thiobarbituric acid reaction. Anal. Biochem. 95, 351-358.

Oliva, M., Garrido, M.C. Sales Márquez, D., González de Canales, M.L., 2009. Sublethal and lethal toxicity in juvenile Senegal sole (Solea senegalensis) exposed to copper: A preliminary toxicity range-finding test. Exp. Toxicol. Pathol. 61 (2), 113-121.

Oliva, M., González de Canales, M.L., Gravato, C., Guilhermino, L., Perales, J.A., 2010 Biochemical effects and polycyclic aromatic hydrocarbons (PAHs) in Senegal sole (Solea senegalensis) from a Huelva estuary (SW Spain). Ecotox. Environ. Environ. Saf. 73, 1842-1851.

Padmini, E., Vijaya Geetha, B., Usha Rani, M., 2008. Liver oxidative stress of the grey mullet Mugil cephalus presents seasonal variations in Ennore estuary. Braz. J. Med. Biol. Res. 41 (11), 951-955.

Padmini, E., Vijaya Geetha, B., 2009. Impact of season on liver mitochondrial oxidative stress and the expression of HSP70 in grey mullets from contaminated estuary. Ecotoxicology 8 (3), 304-311.

Pinto, E., Sigaud-Kutner, T.C.S., Leitão, M.A.S., Okamoto, O.K., Morse, D., Colepicolo, P., 2003. Heavy metal-induced oxidative stress in algae. J. Phycol. 39, 1008-1018.

Pruell, R.J., Engelhardt, F.R., 1980. Liver cadmium uptake, catalase inhibition and cadmium thionein production in the killifish (Fundulus heteroclitus) induced by experimental exposure. Mar. Environ. Res. 3, 101-111.

Quian, Y., Buettner, G.R., 1998. Iron oxygen complexes are important initiators of biological free radical oxidations, 5th Annual Meeting of the Oxygen Society, Washington, DC, November 19-23.

Regoli, F., Gorbi, S., Frenzilli, G., Nigro, M., Corsi, I., Focardi, S., Winston, G.W., 2002. Oxidative stress in ecotoxicology: From the analysis of individual antioxidants to a more integrated approach. Mar. Environ. Res. 54, 419-423.

Regoli, F., Principato, G., 1995. Glutathione, glutathione-dependent and antioxidant enzymes in mussel, Mytilus galloprovincialis, exposed to metal under field and laboratory conditions: Implications for the use of biochemical biomarkers. Aquat. Toxicol. 31, 143-164.

Roche, H., Bogé, G., 1993. In vitro effects of $\mathrm{Cu}, \mathrm{Zn}$ and $\mathrm{Cr}$ salts on antioxidant enzyme activities of red blood cells of a marine fish Dicentrarchus labrax. Toxicology 7, 623-629.

Ronisz, D., Larsson, D.G.J., Förlin, L., 1999. Seasonal variations in the activities of selected hepatic biotransformation and antioxidant enzymes in eelpout (Zoarces viviparus). Comp. Biochem. Physiol. C 124, 271-279.

Ruvio, M., 1972. Marine Pollution and Sea Life. FAO Fishery News Ltd, London.

Schlenk, D., Wolford, L., Chelius, M., Steevens, J., Chan, K.M., 1997. Effect of arsenite, arsenate, and the herbicide monosodium methyl arsenate (MSMA) on hepatic metallothionein expression and lipid peroxidation in channel catfish. Comp. Biochem. Physiol. C 118 (2), 177-183.

Sheehan, D., Power, A., 1999. Effects of seasonality on xenobiotic and antioxidant defense mechanisms of bivalve molluscs. Comp. Biochem. Physiol. C 123, 193-199.

Sheweita, S.A., 1998. Heavy Metal-induced changes in the glutathione levels and glutathione reductase/glutathione S-transferase activities in the liver of male mice. Int. J. Toxicol. 17 (4), 383-392.

Stegeman, J.J., Brouwer, M., Richard, T.D.G., Förlin, L., Fowler, B.A., Sanders, B.M., Van Veld, P.A., 1992. Molecular responses to environmental contamination: Enzyme and protein systems as indicators of chemical exposure and effect. In: 
Huggett, D., Kimerly, R.A., Mehrle Jr, P.M., Bergman, H.L. (Eds.), Biomarkers: Biochemical, Physiological and Histological Markers of Anthropogenic StressLewis Publishers, Chelsea, MI, USA, pp. 235-335.

Stohs, S.J., Bagchi, D., Hassoun, E.,, Bagchi, M., 2001. Oxidative mechanisms in the actin depolymerization. Toxicol. Appl. Pharmacol. 139, 115-121.

Storey, K.B., 1996. Oxidative stress: Animal adaptations in nature. Braz. J. Med. Biol. Res. 29, 1715-1733.

Thomas, D.J., Juedes, M.J., 1992. Influence of lead on the glutathione status of the Atlantic croaker tissues. Aquat. Toxicol. 23, 11-30.

Torres, M.A., Testa, C.P., Gáspari, C., Masutti, M.B., Panitz, C.M.N., Curi-Pedrosa, R., Almeida, E.A., Di Mascio, P., Filho, D.W., 2002. Oxidative stress in the mussel Mytella guyanensis from polluted mangroves on Santa Catarina Island, Brazil. Mar. Pollut. Bull. 44, 923-932.

USEPA (United States Environmental Protection Agency), 2002. National Recommended Water Quality Criteria. EPA-822-R-02-047, Office of Science and Technology.
Vaglio, A., Landriscina, C., 1999. Changes in liver enzyme activity in the teleost Sparus aurata in response to cadmium intoxication. Ecotoxicol. Environ. Saf. 43 (1), 111-116.

Van der Oost, R., Beyer, J., Vermeulen, N.P.E., 2003. Fish bioaccumulation and biomarkers in environmental risk assessment: A review. Environ. Toxicol. Pharmacol. 13, 57-149.

Vicente Martorel, J.J., Galindo-Riaño, M.D., García-Vargas, M., Castro-Granado, D. 2009. Bioavailability of heavy metals monitoring water, sediments and fish species from a polluted estuary. J. Hazard. Mater 162, 823-836.

Watjen, W., Beyersmann, D., 2004. Cadmium induced apoptosis in C6 glioma cells: Influence of oxidative stress. Biometals 17, 65-78.

WHO (World Health Organization), 1992. Environmental Health Criteria, 134. Cadmium, Geneva.

Winston, G.W., Di Giulio, R.T., 1991. Prooxidant and antioxidant mechanisms in aquatic organisms. Aquat. Toxicol. 19, 137-161. 